\title{
LA LIBERTAD DE LOS MODERNOS EN LA SOCIEDAD DIGITAL: "EL CONTROL DE LOS DATOS OS HARÁ LIBRES"
}

\author{
THE MODERN LIBERTY IN DIGITAL SOCIETY: \\ DATA POWER WILL SET YOU FREE
}

\author{
VANesa Morente PARRA \\ Universidad Pontificia Comillas ICADE
}

Fecha de recepción: $22-5-20$

Fecha de aceptación: 14-7-20

Resumen: La sociedad contemporánea ha traído consigo la inmaterialización de la vida, de tal manera que el ciudadano se digitaliza y aprende a transaccionar información en el espacio planetario de la red. Se abre ante nosotros un inagotable mundo de información y comunicación, sin embargo, su precio puede ser muy alto: nuestra libertad. El modelo teórico de la "libertad de los modernos", formulado originalmente por Benjamin Constant, es utilizado aquí como criterio analítico de las dimensiones reales que presenta la libertad digital. ¿Es posible seguir hablando de la "libertad de los modernos" en la sociedad digital? ¿Es posible entender internet como una comunidad politica susceptible de democratización? ¿Debemos transitar hacia otro modelo de libertad? A responder a estas y otras cuestiones dedicaremos el presente artículo.

Abstract: Contemporary society brings an immaterial life, in such a way that the citizen is digitized and learns to exchange information in a virtual network of planetary dimension. An inexhaustible world of information and communication opens up in front of us, however its price can be very high: our freedom. The theoretical model of "modern liberty" announced by Benjamin Constant, it's used here like an analytical criteria of the digital liberty. Is modern liberty possible in digital society? Is it possible to understand the internet as a democratic society? Should we move towards another model of liberty? This article wants to answer these questions.

Palabras clave: libertad, autodeterminación, datos y sociedad digital Keywords: liberty, personal determination, data and digital society

ISSN: 1133-0937

DOI: https://doi.org/10.20318/dyl.2021.6106

DERECHOS Y LIBERTADES

Número 45, Época II, junio 2021, pp. 199-231 


\section{DE "LA LIBERTAD DE LOS MODERNOS" A LA “LIBERTAD NEGATIVA": EL IDEAL EMANCIPATORIO DE LA LIBERTAD}

Doscientos años después de que Benjamin Constant pronunciara su discurso en el Ateneo de París titulado "La libertad de los antiguos comparada con la de los modernos" ${ }^{11}$, parece pertinente analizar el modo, la intensidad y la extensión en los que se ejerce la "libertad de los modernos" en la sociedad digital ${ }^{2}$. Cuando Benjamin Constant formula su alegato en favor de la "libertad de los modernos" en 1819, tiene una clara finalidad de reforzar el ideal revolucionario francés de la libertad individual, de la consagración universal de un acervo de libertades civiles estrechamente vinculadas con la idea de "individuo", teniendo como contrapunto ideológico el nacionalismo que prima a la comunidad política frente al individuo ${ }^{3}$. Para Constant, la libertad que valoramos los modernos se concreta en el disfrute de nuestra individualidad y se garantiza a través de los "derechos subjetivos", que establecen un coto privado donde nuestra soberanía no puede ser lesionada sin que sintamos mermada nuestra libertad ${ }^{4}$.

Con ello, Benjamin Constant procede a diseñar el boceto de lo que a partir de entonces se va a conocer por "libertad moderna". Para ello, parte de la siguiente pregunta: ¿qué es lo que entiende hoy día un inglés, un francés, un habitante de los Estados Unidos por la palabra libertad? Para todos ellos, dirá Constant, es el derecho a no estar sometido más que a las leyes; el derecho de expresar su opinión; el derecho de elegir profesión y ejercerla; el derecho a disponer de su propiedad; a ir y venir sin pedir permiso; el derecho de reunión; el derecho de profesar cualquier religión o no profesarla; y, por

1 Según Ángel Rivero la mejor edición de esta conferencia es la de Benjamin Constant, OEuvres complètes Serie I. XV. Brochures politiques (1819-1821), Berlín, de Gruyter Mouton, 2017.

2 El concepto de "sociedad digital" es preferible al de "mundo digital", ya que el concepto mundo nos remite a algo exterior que sugiere que nos ha sido dado; algo así como la naturaleza. Pero la sociedad digital se ha construido sobre la base de descubrimientos, técnicas, dispositivos y aparatos creados por el ser humano. T. DE LA QUADRA-SALCEDO y J. L. PIÑAR MAÑAS (dir.), Sociedad digital y Derecho, BOE, Ministerio de Industria, Comercio y Turismo, RED.ES, Madrid, 2018, p. 22

3 En realidad, Benjamin Constant tiene un doble cometido al pronunciar su discurso en el Ateneo de París: por un lado, ayudar a combatir el incipiente nacionalismo que estaba emergiendo en algunos países europeos; y, por otro lado, contrarrestar la deriva ideológica, basada en la violencia y el terror, en el que había caído la política francesa postrevolucionaria al confundir, según Constant, la libertad de los modernos con la libertad de los antiguos.

4 Prólogo de Ángel Rivero a la obra de Benjamin Constant, La libertad de los modernos, Alianza, Madrid, 2019, p. 9 
último, es el derecho a influir en la administración del gobierno ${ }^{5}$. Con ello, Constant colabora en la construcción de la libertad individual como contrapunto de lo que él define como la "libertad de los antiguos", la cual consistía en ejercer colectivamente y de forma directa, distintas facetas de la soberanía como deliberar en la plaza pública sobre asuntos tales como la guerra y la paz; acordar alianzas con pueblos extranjeros; votar las leyes; emitir juicios; examinar cuentas públicas; fiscalizar las funciones de los magistrados; $y$, por último, procesar y condenar a los funcionarios ante todo el pueblo. Este tipo de libertad convivía naturalmente con una sujeción completa del individuo a la autoridad del conjunto, manifestada en la regulación de las costumbres y, por consiguiente, en la ordenación de la vida privada ${ }^{6}$. De este modo, entre los antiguos, el individuo era generalmente soberano en los asuntos públicos y un esclavo en todas las relaciones privadas ${ }^{7}$.

De todo ello no se deriva una concepción negativa o peyorativa de la libertad de los antiguos frente a la de los modernos, el único propósito de Constant es poner de manifiesto que el desarrollo y plenitud de la libertad, entendida como participación directa en los asuntos públicos, obedeció a las características sociales y culturales de una época concreta ${ }^{8}$. El individuo moderno, que se encuentra inmerso en comunidades políticas multitudinarias, no puede tener

5 B. CONSTANT, "La libertad de los antiguos comparada con la de los modernos”, en La libertad de los modernos, Alianza Editorial, Madrid, 2019, p. 77.

6 Hannah Arendt afirma que lo que distinguía la convivencia humana en la polis de otras formas de convivencia humana era la libertad, lo que no significa que la política se entendiera como un medio para posibilitar la libertad humana, una vida libre. Arendt advierte que "ser libre y vivir en una polis eran en cierto sentido uno y lo mismo. Pero solo en cierto sentido; pues para poder vivir en una polis, el hombre ya debía ser libre en otro aspecto: como esclavo, no podría estar sometido a la coacción de ningún otro ni, como laborante, a la necesidad de ganarse el pan diario". Por tanto, para Arendt lo político, en la antigua Grecia, se centra en la libertad, entendida esta en un sentido negativo como "no ser dominado", y, positivamente, como "un espacio solo establecible por muchos", en que cada cual se mueva entre iguales. H. ARENDT, ¿Qué es la política? Paidós, Barcelona, 1997, pp. 69 y 70.

7 B. CONSTANT, "La libertad de los antiguos comparada con la de los modernos", cit., p. 79. Hannah Arendt llega a afirmar que para los griegos antiguos la vida privada era "idiota", ya que carece de la diversidad "del hablar sobre algo". Solo en la libertad del conversar, dice Arendt, surge en su objetividad visible desde todos los puntos de vista el mundo del que se habla. La vida privada o doméstica, por tanto, era invisible para los antiguos griegos. H. ARENDT, ¿Qué es la política?, cit., p. 79.

8 Constant destaca tres diferencias fundamentales entre la época clásica y la modernidad: 1. La extensión de los territorios (pequeñas ciudades-estado frente a Estados nación multitudinarios); 2. La abolición de la esclavitud que permitía gozar de tiempo libre a los ciudadanos libres; 3 . El comercio, que no permite intervalos de inactividad en los que dedicarse 
un impacto significativo sobre el conjunto, nada del entorno público deja constancia de su participación. El anhelo de los modernos es la seguridad en los goces privados, de la independencia individual, y llamamos libertad a las garantías que otorgan las instituciones para dicho disfrute ${ }^{9}$. Constant afirma que "la independencia individual es la primera de las necesidades modernas, por lo que jamás puede pedirse su sacrificio para el establecimiento de la libertad política" ${ }^{10}$. Sin embargo, esto no quiere decir que Constant esté renunciando a cualquier tipo de libertad política, entre otras cuestiones porque seguimos siendo titulares de derechos como el de consentir las leyes, deliberar sobre nuestros intereses y ser parte integrante del cuerpo social al que pertenecemos.

De hecho, según Constant, el peligro de la libertad moderna es que absortos en el disfrute de nuestra independencia privada, en nuestra individualidad y en la prosecución de nuestros intereses particulares, renunciemos con demasiada facilidad a nuestro derecho a participar en el poder político ${ }^{11}$. De ahí que Constant finalice su discurso afirmando que, lejos de renunciar a ninguna de las dos especies de libertad, lo que hace falta es aprender a combinar una libertad con otra. La conclusión última, por tanto, es que el mejor modo de combinar ambas libertades es la forma de gobierno que nos proporciona la democracia representativa. Por ello, y como afirma Miguel Saralegui, nunca se consideró que tuviera sentido llamar a un hombre "libre" al margen de su vinculación con lo público, de ahí que hablemos necesariamente de la libertad política, aunque siempre atendiendo a sus modulaciones históricas ${ }^{12}$.

a la vida pública y olvidar los interese privados. B. CONSTANT, “La libertad de los antiguos comparada con la de los modernos", cit., pp. 84 y 85. cit., p. 89 .

B. CONSTANT, "La libertad de los antiguos comparada con la de los modernos",

$10 \quad$ Idem, p. 95.

11 Alexis de Tocqueville muestra un claro rechazo hacia el individualismo que lo entiende como "un sentimiento reflexivo y apacible, que dispone a cada ciudadano a aislarse de la masa de sus semejantes, y a situarse al margen, con su familia y sus amigos; de tal manera que, tras haberse creado así una pequeña sociedad para su uso, abandona con gusto la gran sociedad a sí misma." "El individualismo es de origen democrático, y amenaza con desarrollarse a medida que las condiciones se igualan." "Así, pues, no sólo la democracia hace olvidar a cada hombre sus antepasados, sino que le oculta sus descendientes y le separa de sus contemporáneos; le conduce sin cesar hacia él solo, y amenaza con encerrarle, en fin, por completo, en la soledad de su propio corazón." A. TOCQUEVILLE, La democracia en América, Editorial ORBIS, Barcelona, 1985, pp. 186 y 188.

12 M. SARALEGUI, "La libertad de los modernos y la libertad negativa. Diferencias y similitudes entre los discursos 'liberal' de Constant y Berlin", Thémata, Revista de Filosofía de la Universidad de Sevilla, número 38, 2007, pp. 235-244, p. 237. 
Cuatro décadas después de la publicación de Constant sobre la libertad de los antiguos y los modernos, aparece la gran obra sobre la libertad individual titulada "On liberty" de John Stuart Mill. Según Isaiah Berlin ${ }^{13}$, John Stuart Mill es, indudablemente, el máximo defensor de la libertad individual y el fundador del liberalismo moderno. En su ensayo sobre la libertad, Mill diseña el modelo de "libertad" de las democracias liberales actuales, una "libertad" entendida en sentido negativo, es decir, como la libertad del "laizer faire" y del "to be let alone" ${ }^{14}$. La finalidad de su obra es tratar de definir en qué consiste la libertad civil, a través de la descripción de la naturaleza y límites del poder que puede ser ejercido legítimamente por la sociedad sobre el individuo ${ }^{15}$. Influido por Jeremy Bentham, Mill relaciona el ejercicio de la libertad individual, el ejercicio del pleno desarrollo de la personalidad, con la felicidad, llegando a afirmar que la felicidad humana es una hazaña estrictamente individual. Este es uno de los ámbitos teórico en los que Mill acaba aparatándose de su mentor -Bentham conecta el utilitarismo con una idea de felicidad colectiva, a través de la maximización del mayor número de personas-, para centrar sus energías teóricas en el desarrollo máximo de la libertad individual, o "libre desarrollo de la personalidad".

En los escritos de Mill la felicidad supone la "realización de los propios deseos", sean éstos los que sean ${ }^{16}$. La felicidad se encontraría, por tanto, en la posibilidad que tiene el individuo de desarrollar libremente sus planes o proyectos de vida, sin ninguna injerencia del poder público, ya sea para limitar dicha autorrealización o para imponer un modelo de corrección moral públicamente aceptado. El único objeto que autoriza a la comunidad política

13 Isaiah Berlin prologa la obra de Stuart Mil en 1969 para Oxford University Press.

14 Aquí la libertad se encuentra estrechamente relacionada con el concepto de "intimidad". La primera definición que se otorga al derecho a la intimidad la proporciona el juez Thomas A. Cooley en 1873, entendiendo por tal el "derecho a ser dejado solo o en paz". T. A. COOLEY, A treatise on the law of torts or the wrongs which arise independently of contact, $4 .^{\text {a }}$ ed., Vol. I Callaghan, Chicago, 1932, p. 34. No obstante, son dos abogados de Boston, Samuel Warren y Louis Brandeis, los que conviertan "el ser dejado en paz" en exigencia jurídica elevada a derecho constitucional. S. WARREN y L. BRANDEIS, "The rigth to privacy", Harvard Law Review, vol. IV, núm. 5, 15 December, 1890, p. 195.

15 J. S. MILL, Sobre la libertad, Alianza Editorial, Madrid, primera edición 1970, p. 57.

16 Berlin destaca en su Prólogo cómo Mill se aparta deliberadamente de las tesis utilitaristas de Bentham, cuyo eje central se sitúa en la búsqueda de la felicidad, hasta el punto de que Mill afirma que "la utilidad o la felicidad es algo demasiado complejo e indefinido en tanto fin para ser buscado fuera de la mediación de diferentes fines secundarios con respecto a los cuales puede suceder, y de hecho sucede muy a menudo, que coincidan muchas personas que difieren que difieren en cuanto al fin último", cit., 19. 
a perturbar la libertad de acción, o de elección, de cualquier de sus integrantes es la propia defensa, es decir, la única razón legal que justifica utilizar la fuerza contra uno de los miembros de una comunidad civilizada es la de impedir que se perjudique a otros; pero nunca buscar su propio bien, ya sea este físico o moral ${ }^{17}$.

Si la individualidad es la misma cosa que el desarrollo de la personalidad, y si únicamente el cultivo de la individualidad produce o puede producir seres humanos bien desarrollados ${ }^{18}$, entonces solo en el contexto de sociedades en las que se cultive la individualidad, la espontaneidad e incluso la excentricidad, puede el ser humano alcanzar la felicidad. Las sociedades tradicionales, en las que impera la costumbre, está mal vista la espontaneidad, se persigue al individuo que se sale de lo marcado por la tradición. Un pueblo deja de evolucionar cuando cesa de poseer individualidad y singularidad $^{19}$. Si analizamos esta afirmación de Stuart Mill a través del prisma conceptual que utiliza Constant para clasificar la libertad, Mill estaría entendiendo que únicamente la libertad de los modernos permite al ser humano desarrollar plenamente su personalidad y, por consiguiente, ser feliz ${ }^{20}$. Por tanto, el ideal emancipatorio de Mill se alcanzaría si el individuo pudiera lle-

17 J. S. MILL, Sobre la libertad, cit., p. 68. Precisamente sobre la justificación del uso del Derecho como instrumento de persecución, castigo y disuasión de aquellas conductas privadas que puedan "perjudicar" o poner en riesgo la integridad de la moral pública comunitaria basa Patrick Devlin su obra La imposición de la moral publicada en 1965.

18 J. S. MILL, Sobre la libertad, cit., pp. 137 y 138.

19 Stanislaw Lem refleja magistralmente en uno de sus cuentos el fenómeno de la "homogeneización social" y, por consiguiente, el de la pérdida de la subjetividad y de la singularidad personal, a través de la vida de los habitantes de un planeta llamado Panta. Los habitantes de este planeta dicen haber descubierto "el más alto conocimiento de las fuentes de todos los sufrimientos, preocupaciones y desgracias que padecen los seres unidos en la sociedad. Dicha fuente estriba en el individuo, en su personalidad particular. La sociedad, la colectividad, es eterna y regida por unas leyes constantes e inamovibles, iguales a las que rigen el poderío de soles y estrellas. El individuo se caracteriza por inestabilidad, por falta de decisión, por lo accidental de sus acciones y, sobre todo, por su transitoriedad. Nosotros hemos suprimido totalmente el individualismo a favor de la sociedad. En nuestro planeta solo existe la colectividad: no hay en él individuos". S. LEM, Diarios de las estrellas, Alianza, Madrid, 2005, pp. 142-143.

20 John Stuart Mill establece una relación necesaria entre el libre desarrollo de la individualidad y la felicidad. Afirma Mill que debemos dejar de entender el libre desarrollo de la personalidad como un elemento más de la civilización, la educación y la cultura, sino más bien como parte necesaria y condición indispensable para que se den todas esas cosas. De ese modo no existiría ningún peligro de que la libertad no fuera considerada en su justo valor y no habría que vencer grandes dificultades en trazar la línea de demarcación entre ella y el control social. J. S. MILL, Sobre la libertad, cit., p. 128. 
gar a desarrollar plena y libremente su personalidad sin injerencias injustificadas o ilegítimas por parte de terceros ${ }^{21}$. En el epígrafe siguiente nos plantearemos si se dan estas condiciones ideales en la sociedad digital.

Cien años después de que John Stuart Mill publicara la obra de referencia sobre la libertad individual, Isaiah Berlin pronunció una conferencia titulada "Dos conceptos de libertad" al tomar posesión de su cátedra de Teoría Social y Política de la Universidad de Oxford en 1958. Es indudable que Berlin es deudor tanto de la obra de John Stuart Mill como de Benjamin Constant, hasta tal punto que la construcción teórica que inicia Constant sobre la libertad de los modernos encuentra de alguna manera una continuación en el concepto de "libertad negativa" formulado por Berlin ${ }^{22}$. Y al igual que Constant aprovechó su contexto histórico para consolidar el concepto de la libertad de los modernos frente a la libertad de los antiguos, como ya hemos tenido ocasión de analizar, Berlin hizo lo propio aprovechando la oportunidad que le ofrecía el contexto de la Guerra Fría para reforzar la idea de la libertad negativa frente a la libertad positiva. Isaiah Berlin, emigrante procedente de Letonia, Estado satélite de la antigua Unión Soviética, quiso utilizar la plataforma oxoniense para colaborar en el establecimiento del predominio del bloque ideológico norteamericano, basado en el ideal de la libertad negativa, frente al soviético, basado en el ideal de la libertad positiva como manifestación de la libertad colectiva. Esto le sirvió a Berlin para erigirse como uno de los liberales más cualificados en la contemporaneidad ${ }^{23} \mathrm{y}$, como se-

21 Ya Thomas Hobbes definió la libertad como "la ausencia de impedimentos externos, impedimentos que a menudo pueden arrebatar a un hombre parte de su poder para hacer lo que le plazca, pero no pueden impedirle usar del poder que le queda, de acuerdo con lo que le dicten su juicio y razón". Véase T. HOBBES, Leviatán, (Edición preparada por C. Moya y por A. Escohotado), Editora Nacional, Madrid, 1980, p. 228.

22 Miguel Saralegui reconoce que una gran parte de la bibliografía actual sostiene que el principal inspirador liberal de "Dos conceptos de libertad" es Benjamin Constant, hasta el punto de que hay autores, como Quentin Skinner, que sostienen que ambos autores mantienen un discurso esencialmente homogéneo. Sin embargo, Saralegui demuestra que hay diferencias significativas entre ambos autores. Véase M. SARALEGUI, "La libertad de los modernos y la libertad negativa. Diferencias y similitudes entre los discursos "liberal" de Constant y Berlin", cit., p. 236.

23 Debe tenerse en cuenta que el liberalismo de Berlin es un liberalismo escéptico y pluralista o, en palabras de John Gray, un liberalismo agonista frente al comunismo soviético. Berlin sostuvo siempre la tesis del pluralismo de valores que, a su vez, le llevó a sostener la tesis de la inconmensurabilidad de bienes y males y formas de vida contrarias. La naturaleza del ser humano no está fijada o acabada; es inherentemente incompleta y, por consiguiente, susceptible de transformación, a través de las elecciones que hacemos entre bienes y males 
ñala Miguel Saralegui, uno de los pocos dueños del significado de la palabra libertad ${ }^{24}$.

Berlin constituye el tercer vértice de la tríada de autores que forman lo que aquí se ha denominado el "ideal emancipatorio de la modernidad". Los tres autores seleccionados, han abordado de manera monográfica el fenómeno de la libertad individual, aportando al pensamiento político diferentes teorías más o menos acabadas, más o menos complementarias, pero que, en cualquier caso, delimitan un espacio común de reflexión ${ }^{25}$. Y parece claro que este espacio de reflexión emerge con el individualismo propio de la modernidad, con el giro copernicano que se produce al centrar el eje del pensamiento, científico, filosófico y político, en el ser humano, entendido éste como agente que se autodetermina tanto en un sentido moral como político ${ }^{26}$.

Si bien, la teoría ética kantiana ha gozado de cierta hegemonía como teoría básica que pretende explicar la libertad moral del individuo, al menos desde una perspectiva ideal, no ha sucedido lo mismo con la libertad política. De ahí, que haya teorías que definan la libertad exclusivamente en términos de la independencia del individuo con respecto a la interferencia de gobiernos, corporaciones o particulares; y otras teorías que crean que la libertad consiste en el control colectivo de la vida comunitaria ${ }^{27}$.

Berlin procede a la diferenciación de estos dos tipos de libertad a través de la formulación de dos preguntas: ¿quién me gobierna? Y ¿hasta qué punto sufro la interferencia del gobierno? La primera pregunta hace alusión a la libertad positiva, la segunda a la libertad negativa. El sentido positivo de la

inconmensurables y a las que nos enfrentamos inevitablemente en el curso de nuestras vidas. J. GRAY, Isaiah Berlin, Novatores, Valencia 1996, pp. 182 y 183.

24 M. SARALEGUI, “La libertad de los modernos y la libertad negativa. Diferencias y similitudes entre los discursos "liberales" de Constant y Berlin", cit., pp. 235-244, p. 239.

25 No se nos escapa que el ideal emancipatorio ha operado durante dos siglos como repositorio teórico donde pensadores tales como Kant, Locke, Voltaire, Montesquieu y Tocqueville, han vertido sus aportaciones y reflexiones, de las cuales también son deudores Constant, Mill y Berlin.

26 La autodeterminación moral presupone la existencia del libre albedrío, pues de lo contrario, se asumiría una teoría determinista que anula la voluntad en las decisiones o acciones individuales y, por consiguiente, la responsabilidad moral que se pueda derivar de ello. Sobre el libre albedrío se pronuncia extensamente -contestando a sus críticos- Isaiah Berlin en la Introducción de "Cuatro ensayos sobre la libertad" en I. BERLIN, Cuatro ensayos sobre la libertad, Alianza Editorial, Madrid, 1988, pp. 10 y ss.

27 Charles Taylor incluye en esta última categoría a las teorías de Rousseau y de Marx. CH. TAYLOR, La libertad de los modernos, Amorrortu, Buenos Aires, 1997, p. 257. 
palabra libertad se deriva del deseo por parte del individuo de ser su propio amo. Quiero que mi vida y mis decisiones dependan de mí mismo, y no de fuerzas exteriores, sean éstas del tipo que sean. La libertad positiva podría resumirse en la siguiente frase: "quiero ser un sujeto y no un objeto. Quiero ser alguien y no nadie, quiero actuar y decidir no que decidan por mí" 28 . Berlin resume su concepto de libertad negativa afirmando que el grado de libertad negativa de un hombre está en función de qué, y cuántas, puertas tiene abiertas, de con qué perspectivas se le abren y de cómo están de abiertas. Es decir, la libertad negativa implica una "posibilidad de hacer", una potencialidad de acción, no la acción en sí misma. Por tanto, las teorías negativas de la libertad pueden apoyarse simplemente en un concepto de oportunidad, mientras que las teorías positivas de la libertad se proyectan sobre una concepción de esta que implica, básicamente, el ejercicio de una acción concreta sobre la propia vida. Sin embargo, Charles Taylor entiende que la libertad negativa no puede ser entendida como una mera oportunidad, ya que hay teorías sobre la libertad negativa que incorporan la idea de autorrealización. Estas teorías entienden que no podemos decir que alguien es libre si no se ha realizado en absoluto, es necesario cierto ejercicio de la libertad para considerar libre a una persona ${ }^{29}$.

Otra de las razones por las que Berlin entiende la libertad negativa conceptualmente distinta a la libertad positiva es porque no concibe que deba darse una relación necesaria entre democracia o autogobierno y libertad individual. Afirma Berlin que: "La libertad en sentido negativo no es incompatible con alguna clase de autocracia y con la ausencia de autogobierno. Esta libertad se preocupa principalmente por el área de control y no por la manera en que este poder garantiza la libertad negativa" ${ }^{30}$. Miguel Saralegui pone de manifiesto que la gran diferencia entre Constant y Berlin está precisamente en la relación entre libertad y democracia. Para Constant la relación entre libertad y democracia es necesaria, hasta tal punto que concluye su argumento con la exigencia de la democracia representativa y de la participación para que la libertad de los modernos no perezca ${ }^{31}$. Sin embargo, para Berlin la relación entre libertad individual y democracia es contingente, aunque reconoce que el autogobierno puede proveer de una mejor garantía

\footnotetext{
28 I. BERLIN, Cuatro ensayos sobre la libertad, cit., p. 201.

29 CH. TAYLOR, La libertad de los modernos, cit., p. 260.

30 I. BERLIN, Cuatro ensayos sobre la libertad, cit., pp. 199 y 200.

31 B. CONSTANT, "La libertad de los antiguos comparada con la de los modernos",
} cit., pp. 104 y 105. 
para la preservación de las libertades civiles ${ }^{32}$. De ahí que estos dos autores detecten los peligros para la libertad en ámbitos distintos. Uno de ellos es el mercado, llegando a afirmar Constant que "al propio mercado y a la propiedad se le debe el amor del hombre a la libertad individual". Para el pensador suizo, sin el mercado, no nace ni el individuo ni el gusto por la libertad privada $^{33}$. Por el contrario, para Berlin el mercado puede convertirse en una de las principales fuentes de opresión y liberticidio, ya que la libertad de los lobos frecuentemente ha significado la muerte de las ovejas ${ }^{34}$. El segundo foco de peligros es la libertad positiva. Si Constant ve el peligro para la libertad negativa en una sociedad completamente despolitizada, olvidada de lo político, Berlin encuentra el peligro en la misma libertad positiva que puede convertirse en fuente de totalitarismo, hasta el punto de llegar a afirmar que siempre que nos ocupemos de la libertad grupal, surge la posibilidad de que la comunidad destruya al sujeto ${ }^{35}$.

Si bien es cierto que los tres autores que hemos analizado, y que han contribuido muy activamente a construir el ideal emancipatorio de la Modernidad, presentan claras diferencias en algunos aspectos de sus teorías sobre la libertad política, no es menos cierto que estas tres concepciones de la libertad se soportan en un mismo sustrato ideológico, ya que comparten una misma comprensión de la naturaleza humana. El ser humano es entendido por estos tres autores como un ser digno -sujeto titular de derechos individuales- que se autodetermina en un sentido psicológico, moral y político. El eje central de sus teorías políticas es el individuo, que emerge en la Modernidad como razón última de toda reflexión. Tanto Constant como Berlin dejan claro en sus estudios históricos sobre la libertad individual, que en la Antigüedad no había surgido con claridad la cuestión de la libertad individual, es decir, la cuestión de que no deba permitirse a la autoridad pública, sea ésta laica o eclesiástica, que traspase unos determinados límites. La idea de la libertad individual como la oportunidad de actuar o de decir sin obstáculos, no surgió expresamente en la Antigüedad porque no era fundamental para los griegos, ni tampoco para ninguna otra civilización que hayamos conocido. Sin embargo, la libertad negativa ha sido fundamental en la Modernidad y sigue siéndolo en la actualidad, treinta años después de que

32 I. BERLIN, Cuatro ensayos sobre la libertad, cit., p. 200.

33 M. SARALEGUI, "La libertad de los modernos y la libertad negativa. Diferencias y similitudes entre los discursos "liberales" de Constant y Berlin", cit., p. 240.

34 I. BERLIN, Cuatro ensayos sobre la libertad, cit., p. 47.

35 Idem, pp. 203 y 204. 
Francis Fukuyama sentenciara el fin de la historia, al caer el muro de Berlin en $1989^{36}$.

Cayó el muro de Berlín, y con él el comunismo, para dar paso al liberalismo que hasta la fecha se ha erigido como el modelo político y económico hegemónico, frente a cualquier alternativa ideológica que pretenda organizar la vida pública. Fukuyama entiende la democracia liberal occidental como la "forma final del gobierno humano", en la que puede experimentarse el dominio del liberalismo sobre todo en la esfera de las ideas o de la conciencia. Este dominio inmaterial del liberalismo se hará extensivo a largo plazo, según el autor, al mundo real o material, de tal modo que el liberalismo dominará todas las esferas de la realidad humana. Y, hasta hace apenas unos meses, los augurios de Francis Fukuyama en relación con el imperio del liberalismo habían sido ciertos. Sin embargo, Fukuyama no contaba ni con un desarrollo tecnológico con vocación absolutista, ni con los imponderables naturales que pueden transformar nuestra forma de entender tanto la vida pública como la vida privada. Actualmente, desde nuestra nueva naturaleza híbrida material-digital, estamos siendo testigos de un hecho histórico ${ }^{37}$ que, inevitablemente, lo va a cambiar todo. Incluso, puede llegar a cambiar la manera en la que entendemos la libertad individual y, por consiguiente, las garantías jurídicas que el Estado ha de prestar para proteger los derechos fundamentales y las libertades individuales. Llegado ese momento, tendremos que plantearnos si podemos seguir entendiendo la libertad negativa como la hemos entendido en la Modernidad o, si por el contrario, y situándonos en el supuesto más extremo, tendremos que replantearnos incluso si la libertad negativa es la única y última libertad posible y deseable para la sociedad digital del siglo XXI.

\section{LA LIBERTAD DE LOS MODERNOS EN LA SOCIEDAD DIGITAL: LA AUTODETERMINACIÓN INFORMATIVA}

El ideal emancipatorio de la Modernidad, entendido este como la libertad de los modernos, nos proporciona un paradigma con el que analizar las dimensiones de la libertad individual en la sociedad digital. La cuestión de la que podemos partir es la siguiente: ¿la sociedad digital proporciona, o puede proporcionar, la consecución del ideal emancipatorio que arrancó ya

\footnotetext{
$36 \quad$ F. FUKUYAMA, ¿El fin de la historia?, Alianza, Madrid, 2015, pp. 56 y 57.

37 Me refiero a la pandemia del COVID-19 que el mundo está padeciendo desde finales de 2019.
} 
en la Ilustración y que ha vertebrado la vida pública, al menos en Occidente? $\mathrm{O}$, por el contrario ¿nos dirigimos hacia la consolidación de un modelo de libertad alternativo?

Para John Stuart Mill, como ya se ha visto, solo podemos hablar de libertad individual en el marco de comunidades políticas no excesivamente tradicionales, en las que, no solo se haya llevado a cabo una clara diferenciación entre vida privada y vida pública, sino que además en esta última deba darse cierto dinamismo social, a través de la espontaneidad, la genialidad y la originalidad. Y si hay algo que se valora en la sociedad digital por encima de todo -al menos aparentemente- es la individualidad, la autenticidad, e incluso la excentricidad. La sociedad digital supone la abolición de las tradiciones como "modelos de corrección moral", y el ensalzamiento del individuo como agente autónomo en el sentido más radical que se haya conocido nunca.

A priori, en la sociedad digital, el individuo puede desarrollar plenamente su personalidad, a través de elecciones libres, consentidas, informadas, etc. Es decir, puede ejercer plenamente su derecho de autodeterminación informativa. Por ello, tanto desde la concepción de Mill como desde la de Constant y Berlin, la sociedad digital habría conseguido maximizar su ideal emancipador. El fenómeno de internet supone la conquista de un espacio público a escala planetaria, cuya virtud consiste precisamente en tener un efecto multiplicador sobre las posibilidades que tiene un individuo de ejercer sus libertades negativas y, por consiguiente, de desarrollar plenamente su personalidad.

La libertad de los modernos, o libertad negativa, requiere como condición de posibilidad el disfrute individual de un espacio público claramente diferenciado del privado, de ahí que no tenga sentido hablar de libertad negativa en la época clásica, como ya nos advirtió Constant. La sociedad digital ha venido a dinamitar, en cierto modo, las fronteras entre lo público y lo privado, proporcionando un espacio público heterogéneo en el que convergen todos los actores sociales: particulares, asociaciones, empresas, instituciones y Estados. Y si en el territorio virtual no hay fronteras ¿qué naturaleza tiene internet? ¿se trata simplemente de un espacio público o de un espacio público de naturaleza política? ¿Constituye la sociedad digital una comunidad política? Si lo fuera ¿sería una comunidad política democrática? A intentar dar respuesta a estas preguntas vamos a dedicar el epígrafe siguiente. 


\subsection{Naturaleza de la sociedad digital: ¿es la sociedad digital una co- munidad política?}

Para llegar a una definición más o menos canónica de lo que es una comunidad política, podemos partir de la definición que nos proporciona Aristóteles en su obra "Política". Aristóteles procede a la definición de lo que es una comunidad política por descarte, es decir, desechando primero lo que no puede ser entendido como tal. Una comunidad cívica o ciudad no es simplemente una comunidad de personas vinculadas con un territorio delimitado, unidas con la finalidad de protegerse mutuamente, y de promover el intercambio comercial entre ellos ${ }^{38}$. Si bien para Aristóteles estos son requisitos necesarios para la constitución de una comunidad cívica, no son suficientes. Una comunidad cívica se define por estar constituida por sujetos diferentes, aunque relacionados todos ellos por el principio de igualdad en la reciprocidad, y cuyo fin es perseguir un bien superior como es el bien común ${ }^{39}$.

En el mismo sentido que Aristóteles, Hannah Arendt concibe la esfera pública caracterizada por la igualdad -como isegoría e isonomía- y vinculada indisolublemente a los conceptos de libertad y distinción. Por naturaleza los seres humanos no son iguales, necesitan de una institución política para llegar a serlo, la cual viene representada por la ley. "El espacio político, por tanto, no es una mera localización física de un ámbito en que las acciones sean visibles sino algo vinculado a la necesidad de límites, delimitado por leyes". Las leyes son precisamente las que vienen a fijar las fronteras del espacio común o del "mundo común", entendido este como comunidad de cosas, que nos une, agrupa y separa, a través de relaciones que no supongan la fusión de los agentes integrantes de la comunidad ${ }^{40}$. Según Hannah Arendt la condición indispensable de la comunidad política es la irreductible pluralidad que queda expresada en el hecho de que somos alguien y no algo. La comunidad política cohesiona a estos "alguien" desde su diversidad caótica, ya que "los hombres se organizan políticamente según determinadas comunidades esenciales en un caos absoluto, a partir de un caos absoluto de las diferencias" ${ }^{41}$.

ARISTÓTELES, Política, Alianza Editorial, Madrid 2018 (2ª edición 2015), p. 161

Aristóteles entiende que el "bien común" deriva de una misma idea compartida sobre la vida feliz y bella, la cual puede consolidarse en la convivencia comunitaria a través de la amistad. Ídem (1281a).

40 H. ARENDT, ¿Quées la política?, cit., p. 21.

41 H. ARENDT, ¿Qué es la política?, cit., p. 4 
Si bien podemos asumir que internet constituye un verdadero espacio de pluralidad, diversidad y libertad, estas características son insuficientes como para elevar internet a la categoría de "comunidad política". Para ello tendríamos que estar en disposición de poder identificar más elementos constitutivos de una comunidad política. En primer lugar, tendríamos que estar en disposición de identificar un elemento importantísimo en la teoría política aristotélica: el interés o intereses comúnmente compartidos por los miembros integrantes de la comunidad política. En segundo lugar, deberíamos poder identificar otros elementos característicos de una comunidad política, tales como las normas que regulan la convivencia de la comunidad, la autoridad competente para aprobar dichas normas y, por últimos, los procedimientos que se siguen para ello.

Como usuarios de internet $\mathrm{y}$, por consiguiente, miembros integrantes de la sociedad digital, podríamos identificar como intereses comúnmente compartidos un uso libre y seguro de la red. El uso libre de la red significa que cada usuario pueda desarrollar de manera autónoma su personalidad a través del ejercicio pleno de su libertad de elección -es decir, a través del desarrollo pleno de sus libertades negativas como la libertad de expresión, artística, ideológica, religiosa, etc.-, por supuesto, sin interferencias ilegítimas por parte de terceros, ya sean estos agentes públicos o privados. Por su parte, un uso seguro de la red implica que la información pública sea veraz y accesible -dando cumplimiento así al principio de transparencia-, y que la información personal goce de la protección jurídica necesaria como para garantizar el anonimato ${ }^{42}$. La posibilidad de ejercer la libertad individual, la seguridad en el tratamiento de la información personal y la transparencia y veracidad de la información pública constituyen, por consiguiente, los bienes comunes a preservar en la comunidad digital.

Ahora solo quedaría intentar responder a la pregunta que se planteaba Isaiah Berlin en relación con la libertad positiva: ¿quién o quiénes detentan el poder de regular y garantizar dichos intereses comunes en la sociedad digital? Es decir ¿Quién o quiénes detentan la autoridad competente sobre la comunidad política y, por consiguiente, administran legítimamente los intereses compartidos por la comunidad digital?

42 El desarrollo legislativo más ambicioso y, por consiguiente, más garante del derecho a la privacidad se ha conseguido en el marco de la UE, a través de la aprobación del Reglamento (UE) 2016/679 del Parlamento Europeo y del Consejo de 27 de abril de 2016 relativo a la protección de las personas físicas en lo que respecta al tratamiento de datos personales y a la libre circulación de estos datos. 
Desde las teorías contractualistas sabemos que las reglas del juego de una comunidad política quedan fijadas en el denominado "contrato social". Para Hobbes, los ciudadanos pueden llegar a un acuerdo de carácter político formando una sociedad civil, o comunidad políticamente organizada, por miedo a los otros o por estrategia auto interesada. Por lo tanto, no buscamos asociarnos con otros por la asociación misma, sino porque de ella podemos recibir algún honor o beneficio. De hecho, Hobbes afirma que las asociaciones mercantiles tienen la única finalidad de satisfacer un interés propio. Si para desempeñar algún menester se produce una cierta amistad, opina Hobbes, esta siempre será de conveniencia, basada más en la envidia que en la verdadera amistad, y de la que a veces pueden surgir algunas facciones y grupos, pero nunca buena voluntad ${ }^{43}$. Obviamente, no todas las relaciones que se dan en el contexto de la sociedad digital tienen este carácter interesado, malevolente y cainita, sin embargo, buena parte de ellas son de carácter comercial y, por consiguiente, interesado. Esto pone de manifiesto que internet no es un espacio político, sino que en realidad es un espacio público de naturaleza múltiple.

Según Hobbes, los pactos y convenios solo se pueden llevar a cabo sobre aquellas cosas que están bajo nuestra deliberación, es decir, no puede haber convenio si falta la voluntad del contratante. La voluntad de hacer o no hacer algo, es el resultado último de una deliberación previa, lo que se deduce de los convenios que se refieren a cosas posibles o que están por venir ${ }^{44}$. Los ciudadanos del modelo teórico de Hobbes deliberan para elaborar un contrato civil, basado en un pacto de no agresión, y en virtud del cual ceder su libertad -entendida como la posibilidad que todo hombre tiene de hacer uso de sus propias facultades de acuerdo con la recta razón- ${ }^{45}$ en un solo centro de poder, del cual emanarán las normas y las sanciones. La obediencia a ese soberano único reside en la segunda ley de la naturaleza "que un hombre esté dispuesto, cuando otros también lo están tanto como él, a renunciar a su derecho a toda cosa en pro de la paz, y defensa propia que considere necesaria, y se contente con tanta libertad contra otros hombres como consentiría a otros hombres contra él mismo" ${ }^{46}$. El contrato social consiste, por consiguiente, en la transferencia mutua de un derecho, de tal manera que cuan-

43 T. HOBBES, De cive, Alianza Editorial (trad. Carlos Mellizo), Madrid, 2000, p. 55

$44 \quad$ Idem, pp. 73 y 74.

45 Idem, p. 60.

46 T. HOBBES, Leviatán, (edición preparada por C. Moya y por A. Escohotado), Editora Nacional, Madrid, 1980, p. 229. 
do "la transferencia de un derecho no es mutua, sino que una de las partes transfiere con la esperanza de ganar por ello amistad o servicio de otro o de sus amigos, o con la esperanza de ganar reputación, de caridad y magnanimidad (...), esto no es contrato sino obsequio, donación, gracia, palabras que significan una y la misma cosa ${ }^{47}$.

Los obstáculos que amenazan la conservación del hombre en el estado de naturaleza suponen para Rousseau -aunque, a diferencia de Hobbes, no parte de una concepción tan negativa del estado de naturaleza- la razón fundamental por la que los seres humanos unen sus fuerzas formando, por agregación, una sola fuerza que pueda exceder a la resistencia y hacerla obrar en armonía. Los seres humanos deben encontrar una forma de asociación que defienda y proteja de toda fuerza común a la persona y a los bienes de cada asociado, y en virtud de la cual cada uno, uniéndose a todos, no obedezca sino a sí mismo y quede tan libre como antes. "Tal es el problema fundamental, al cual da solución el contrato social" ${ }^{48}$. Tanto el Leviatán de Hobbes como la "voluntad general" de Rousseau, son el resultado de la enajenación total de cada asociado con todos sus derechos a toda la comunidad; porque, en primer lugar, dándose cada uno por entero, la condición es la misma para todos, nadie tiene interés en hacerla onerosa a los demás ${ }^{49}$.

Por último, el consentimiento también constituye la llave que abre la posibilidad de establecer un pacto o contrato social entre hombres libres según John Locke. Todos los hombres son libres, iguales e independientes por naturaleza, por lo que nadie puede ser sometido a un poder político que pueda limitar dichas cualidades naturales, a menos que consienta libremente en ello: "el único modo en que alguien se priva a sí mismo de su libertad natural y se somete a las ataduras de la sociedad civil es mediante un acuerdo con otros hombres, según el cual todos se unen formando una comunidad, a fin de convivir los unos con los otros de una manera confortable, segura y pacífica, disfrutando sin riesgo de sus propiedades respectivas." ${ }^{50}$ El ejercicio de la libertad individual en Locke se encuentra estrechamente relacionado con la posesión de propiedades privadas, de hecho el derecho a la intimidad y privacidad encuentra su razón primera en la exclusión de otros del "espacio

$47 \quad$ Idem, p. 232.

48 J. J. ROUSSEAU, El contrato social, biblioteca de El Mundo, Madrid, 2011, p. 26

49 Ibidem.

50 J. LOCKE, Segundo tratado del gobierno civil, Alianza Editorial, Madrid, 1990, p. 111.

DERECHOS Y LIBERTADES

ISSN: 1133-0937

Número 45, Época II, junio 2021, pp. 199-231

DOI: https://doi.org/10.20318/dyl.2021.6106 
privado". Esta herencia teórica se refleja en la concepción del derecho a la autodeterminación informativa como "gestión del patrimonio inmaterial".

La teoría contractualista puede ayudarnos a responder a la cuestión que nos hemos planteado unas líneas más arriba: ¿es la sociedad digital una comunidad política democrática ${ }^{51} \mathrm{Si}$ entendemos que la sociedad civil encuentra su mito fundacional en el contrato social, tenemos que concluir que la sociedad digital no es una comunidad política y, por consiguiente, tampoco podemos pretender que sea una comunidad política democrática. Los usuarios de la sociedad digital no "firmamos" un contrato social, sino un "contrato de adhesión" sobre el que no ejercemos ninguna soberanía, puesto que no podemos modificar ninguna de sus cláusulas. Es decir, los individuos integrantes de la sociedad digital no deliberamos ni sobre procedimientos ni, lo que es aún peor, sobre la constitución o nombramiento de una autoridad competente de la que emanan las normas conductuales y sancionadoras. Sin embargo, autores como José María Lasalle entienden que estamos en el marco de un nuevo contrato social del que surgirá el nuevo Leviatán postmoderno, lo que va a suponer "la renuncia de los seres humanos a la garantía analógica de sus derechos, pero a cambio de que se vean asistidos en su nueva identidad por una técnica que crece exponencialmente en su poder de acción y les promete la utopía del paraíso digital" ${ }^{52}$. En este contexto, y según este autor, en la actualidad la democracia liberal ha colapsado como consecuencia del impacto que produce la disrupción tecnológica, lo que ha tenido como consecuencia, por un lado, la generación de una ciudadanía inconsciente e irresponsable del ejercicio de sus derechos; y por otro, la desconexión práctica entre la democracia y la racionalidad, cuya consecuencia inmediata es el florecimiento de los populismos" ${ }^{25}$.

51 Asumimos aquí la definición que da Norberto Bobbio de "democracia" en su obra El futuro de la democracia, en la que entiende que una sociedad democrática es aquella comunidad política caracterizada por un conjunto de reglas que establecen quién está autorizado para tomar las decisiones colectivas y bajo qué procedimientos. Para que las decisiones puedan ser adoptadas por unos pocos individuos y ser asumidas y cumplidas por el resto, la autoridad -legitimidad- de aquel debe radicar en una elección previa adoptada por todos en igualdad de condiciones, y como resultado de la aplicación de la regla de la mayoría. Es necesaria una última condición: es indispensable que aquellos que están llamados a decidir o a elegir a quiénes deberán decidir, tengan reconocidos ciertos derechos y libertades fundamentales. N. BOBBIO, El futuro de la democracia, Fondo de Cultura Económica, México, 1986 ( $1^{\text {a }}$ edición en español).

52 J. M. LASALLE, Ciberleviatán, Arpa, Barcelona, 2019, p. 22.

53 Idem, pp. 74 y 75. 
No obstante, asumir que estamos en presencia de un nuevo Leviatán supondría tanto como entender, de algún modo, que los usuarios de internet en algún momento han fungido como ciudadanos participando activamente de la construcción de la estructura de "poder digital", y que han cedido conscientemente, tras una deliberación inter pares, sus derechos y libertades fundamentales para que estos sean custodiados y garantizados por el nuevo poder constituido. Sin embargo, el espacio digital simplemente ha venido a replicar de manera aumentada los males propios del matrimonio entre democracia liberal y capitalismo. El espacio público de la democracia representativa ha sido fagocitado poco a poco por el mercado, por lo que los individuos han ido cambiando paulatinamente su condición de ciudadanos por la de consumidores y usuarios. En el espacio político de la democracia liberal impera el sufragio universal, sin embargo, en el mercado domina un sufragio "capacitario", a través del cual el consumidor que compra no solo obtiene un producto o un servicio, sino que "vota" con su dinero la calidad de estos e, indirectamente, la diferenciación adquisitiva de cada individuo. Esta participación desigual manifestada en el espacio público se ha traslado mutatis mutandis a la sociedad digital, replicando y aumentando el esquema de nuestras sociedades occidentales modernas. Ya nos advirtió Constant que el individuo moderno es independiente en su vida privada, pero no es soberano más que en apariencia, incluso en los Estados más libres ${ }^{54}$. Este hecho sigue siendo constatable en nuestras democracias actuales, en las que depositamos en terceros la gestión de los intereses públicos porque ni queremos, ni podemos gestionarlos nosotros mismos, ya que la vida privada es nuestra prioridad.

La sociedad digital es una comunidad de dimensión planetaria y de naturaleza pública en la que las relaciones se dan de manera asimétrica y en contextos heterogéneos: mercantil, político, social, etc. Es cierto que el espacio público virtual se encuentra gestionado en su práctica totalidad por multinacionales, lo que nos lleva a reafirmar el reduccionismo que supone equiparar a la sociedad digital con una comunidad política democrática. Esto, supondría la mercantilización del ágora o cambiar el ágora por el zoco. Tampoco los actores principales en internet son los Estados soberanos, ni las agrupaciones políticas regionales constituidas por algunos de estos Estados, como la Unión Europea, sino las grandes multinacionales como

54 B. CONSTANT, "La libertad de los antiguos comparada con la de los modernos", cit., p. 80 . 
Google, Amazon, Facebook y Apple ${ }^{55}$. Estas grandes multinacionales, y no los Estados, son en realidad las administradoras de buena parte de la información que fluye constantemente por internet. Aunque, como veremos más adelante, este hecho se ha visto alterado en los últimos meses por la pandemia del coronavirus o Covid-19, en la que han emergido los Estados como los grandes gestores de la información sanitaria.

Tanto si analizamos la sociedad digital desde una perspectiva holística como si la analizamos sectorialmente, atendiendo a sus diferentes elementos integradores como webs, redes sociales, blogs, aplicaciones, etc., llegamos a la conclusión de que internet es un mercado y no una plaza pública de deliberación política. El ejemplo por antonomasia del ejercicio del dominio mercantil en la red lo encontramos en Facebook. Por mucho que Mark Zukerberg, CEO de dicha empresa, se empeñe en hablar de la "comunidad Facebook", como si realmente fuera un espacio comunitario compartido por los usuarios, no lo es. Los miembros integrantes de una comunidad participan activamente y deciden sobre aspectos relacionados con la convivencia en dicha comunidad, sin embargo, los usuarios de Facebook solo deciden relativamente sobre la gestión de algunos contenidos ${ }^{56}$. Por tanto, no hay una comunidad real sino un "individualismo interconectado" a través de una plataforma de observación y autocontemplación en la que los usuarios, que no ciudadanos, ni deliberan ni deciden sobre aspectos fundamentales, tales como la política interna de establecimiento de estándares de corrección moral, la estructura de la red social o la gestión de la publicidad. Facebook no es otra cosa que una multinacional cuyos servicios utilizamos a cambio de dar nuestra información personal, información que entendemos bien custodiada, aunque no siempre ha sido asi ${ }^{57}$.

55 Conocidas como GAFA.

56 Ha de tenerse en cuenta la Sentencia de la Sala Segunda del Tribunal Constitucional 27/2020, de 24 de febrero, a través de la cual se exige el consentimiento expreso y específico para que un tercero pueda descargarse una imagen de un perfil de Facebook, ya que esta ha sido colgada en este sitio web para ser contemplada in situ, no para que sea replicada en otros espacios digitales sin el consentimiento del titular.

57 Un claro ejemplo de la pérdida de control efectivo sobre nuestra información personal es el caso de "Cambridge Analytica". La empresa Facebook estuvo envuelta en uno de los mayores escándalos de filtrado de datos masivos. Después de una investigación periodística llevada a cabo por varios medios de comunicación norteamericanos, salió a la luz a mediados del mes de marzo del año 2018 la filtración irregular de datos personales de cerca de 50 millones de clientes estadounidenses de la empresa Facebook a la compañía británica Cambridge Analytica. La consultora británica obtuvo los datos a través de una aplicación de perfilado psi- 
El tejido virtual de internet ofrece una realidad caleidoscópica trufada de espacios diversos, donde los individuos se comportan como usuarios, consumidores, creadores de recursos, meros observadores y ciudadanos. La sociedad digital es una comunidad coparticipada por Estados, instituciones, empresas, asociaciones e individuos. A nadie se le escapa que esta coparticipación no es igualitaria, sin embargo, internet simplemente refleja la jerarquización y reificación que ya lleva a cabo el sistema capitalista en el mundo analógico. Los déficits democráticos no son exclusivos de internet, sino que son propios de la sociedad material, de la realidad analógica. Bobbio señala que uno de los problemas que presenta la democracia liberal actual es que es "centrífuga", en el sentido de que no tiene un solo centro de poder, sino muchos, y merece el nombre, de sociedad policéntrica o poliarquía ${ }^{58}$. Esto es precisamente lo que pasa en la sociedad digital, no hay un solo soberano, no existe una sola ciudadanía, como cuerpo unitario, que haya depositado la facultad de normar y sancionar en un poder centrípeto de carácter representativo. Lo único que se da en la sociedad digital es una amalgama de poderes, informe, diluido en cuerpos intermedios que forman grupos contrapuestos, en competencia por la información y, por consiguiente, por el dinero ${ }^{59}$.

Por último, no podemos obviar el componente histórico y cultural que condiciona la forma en la que se organizan políticamente las diferentes comunidades humanas que integran el mundo. La sociedad digital es una comunidad planetaria, en la que se representan las diferentes concepciones que se tienen a nivel global sobre la gestión de lo público y, como sabemos, hay Estados que no se regulan de una manera democrática. Por ejemplo, el

cológico desarrollada por un investigador de la universidad de Cambridge llamado Aleksander Kogan, que permitía acceder a información no solo de quienes utilizaban la herramienta, sino también de sus amigos. Supuestamente, los datos fueron recabados por Cambridge Analytica quebrantando las normas de Facebook. La información obtenida se utilizó para perfilar votantes y dirigirles propaganda política personalizada y noticias falsas. Eso les permitió influir en las elecciones estadounidenses de 2016 y también, a través de empresas vinculadas, en otros procesos electorales como el referéndum del Brexit. De este escándalo se derivaron dos consecuencias inmediatas para Facebook, la primera fue el denominado "carrusel de disculpas" que desde el mes de abril tuvo que emprender Mark Zuckerberg, como CEO de la empresa, comenzando en el Senado de los EE.UU. y acabando en la sede del Parlamento Europeo en Bruselas. La segunda se ha manifestado en un cambio radical de las políticas de privacidad de la empresa, pasando a adoptar una filosofía de protección de datos proactiva tal y como le exige el nuevo Reglamento General de Protección de Datos en el espacio europeo.

58 N. BOBBIO, El futuro de la democracia, cit., p. 18.

59 Ídem, p. 17. 
Estado chino y el Estado norcoreano regulan internet de manera autoritaria, como si se tratara de una extensión de su territorio. La pandemia del coronavirus ha venido a mostrarnos cómo Estados totalitarios, o poco democráticos, han utilizado información personal obtenida sin consentimiento expreso para atajar la expansión del virus, justificando dicha acción en la incuestionable "razón de salud pública" 60.

Podríamos exigir que la sociedad digital fuera democrática si todos los Estados del mundo lo fueran, si el Consejo de Seguridad de Naciones Unidas lo fuera, si el Fondo Monetario Internacional lo fuera, o si las multinacionales lo fueran. Si no todos los agentes intervinientes en el tablero internacional tienen una naturaleza democrática no podemos pretender que internet lo sea plenamente.

Parece claro, por tanto, que los usuarios de internet no hemos participado en un proceso constituyente del que hayan emanado las instituciones competentes para reglar y sancionar legítimamente a los ciudadanos digitales. Pero lo que es aún peor, es la toma de conciencia sobre nuestra incapacidad para identificar exactamente qué o quiénes gestionan el poder, es decir, la información en internet. La comunidad digital se caracteriza por ser un espacio inconmensurable y opaco, que hace muy complicado identificar los centros de poder, así como los procedimientos que se siguen en el tratamiento de los datos, macrodatos y metadatos. La lógica algorítmica impera y no está al alcance de todos.

Lo que también parece escapar al control público es la posibilidad de garantizar que la información que fluye libremente por la red sea veraz, incluso siendo este uno de los intereses compartidos por la mayoría de los internautas. Precisamente con la finalidad de garantizar que la información que fluye por internet sea veraz la UE ha decidido combatir lo que denomina "desinformación", mediante la creación del Grupo de Expertos de Alto Nivel sobre Noticias Falsas y Desinformación. Este organismo, a través de su último informe, ha recomendado exigir una mayor transparencia a las plataformas en

60 Byung-Chul Han ha manifestado, en relación con la gestión de la pandemia del Covid-19, que los Estados asiáticos tienen una mentalidad autoritaria, que les viene de su tradición cultural (confucionismo) y se dirigen a personas más obedientes que las europeas y que, además, confían más en el Estado. Por eso, los países asiáticos han apostado fuertemente por la vigilancia digital y, sobre todo, por el Big Data, lo que les ha hecho manifiestamente más eficiente frente a la pandemia que los países de cultura occidental. B. CH. HAN, "La emergencia viral y el mundo de mañana", Sopa de Wuham, ASPO (Asilamiento social preventivo y obligatorio), p. 99. https://www.elextremosur.com/files/content/23/23684/sopa-de-wuhan.pdf. 
línea y las redes sociales ${ }^{61}$. Sin embargo, en plena pandemia del COVID-19, estamos asistiendo a una bochornosa sucesión de noticias falsas que está resultando tan difícil de atajar como el propio virus ${ }^{62}$. Las denominadas "fake news" son reflejo del auge de la propaganda y la baja credibilidad de los medios de comunicación, lo que pone en serio riesgo una posible consolidación de la democracia en la sociedad digital ${ }^{63}$. Sólo garantizando una gestión transparente y responsable de la información que circula por internet, así como un efectivo autogobierno sobre los datos personales, podríamos tener cierta esperanza en la democratización del espacio virtual, al menos de algunos sectores de la red. Si bien somos conscientes de la dificultad de lo primero, quizá haya alguna esperanza en lo segundo y consigamos garantizar efectivamente el autogobierno sobre nuestra información personal. A analizar esta posibilidad vamos a dedicar el epígrafe siguiente.

\subsection{Naturaleza de la libertad digital: la autodeterminación informativa}

Retomando lo que ya hemos anunciado unas líneas más arriba, si la libertad de los antiguos es la libertad positiva, entendida como autodeterminación política, y la libertad de los modernos es la libertad negativa entendida esta como delimitación de un espacio privado, físico e intelectual de no dominación, donde los poderes públicos no entran, la libertad en la sociedad digital es la libertad como autodeterminación informativa. El derecho fundamental a la autodeterminación informativa tiene la función de garantizar a los ciudadanos unas facultades de información, acceso y control a los datos que les conciernen ${ }^{64}$. De hecho, en el discurso académico se habla no solo de la necesidad de proteger los datos personales, sino de la necesidad de ga-

61 https://ec.europa.eu/digital-single-market/en/news/final-report-high-level-expert-group-fakenews-and-online-disinformation

62 El mal endémico de las denominadas "fake news" ya lo hemos padecido en otros episodios como con la intervención del Gobierno ruso en procesos diferentes electorales de todo el mundo (la elección de Donal Trump, el Brexit, la consulta sobre la independencia de Cataluña, etc.). E. GAMERO CASADO, "El derecho digital a particular en los asuntos públicos: redes sociales y otros canales de expresión”, en T. DE LA QUADRA-SALCEDO y J. L. PIÑAR MAÑAS (dirs.), Sociedad digital y Derecho, cit., p. 232.

63 R. RUBIO NUÑÉZ, "El derecho a la información y el derecho al voto", en T. DE LA QUADRA-SALCEDO y J. L. PIÑAR MAÑAS (dirs.), Sociedad digital y Derecho, cit., p. 475

64 A. E., PÉREZ LUÑO, "Intimidad y protección de los datos personales: del habeas corpus al habeas data", en L. GARCÍA SAN MIGUEL (ed.), Estudios sobre el derecho a la intimidad, Tecnos, Madrid, 1992, p. 39. 
rantizar un espacio de "autodeterminación" informativa que permita el libre desarrollo de la personalidad.

El derecho a la autodeterminación informativa estaría compuesto entonces por la libertad general de acción, es decir, la libertad para decidir la realización u omisión de determinados actos; y por la autodeterminación informativa stricto sensu, que comprende la libertad para determinar quién, qué y con qué fin pueden conocer informaciones que conciernen a cada sujeto. Por lo tanto, el derecho a la autodeterminación informativa implica una dimensión de "empoderamiento" del titular de la información personal, que en la sociedad digital puede quedar desdibujada como veremos en el siguiente epígrafe. El ciudadano actual, a través de su actividad en la red, construye su "yo digital" -o "alter ego informático"-, que viene a constituir una parte ineludible de nuestra identidad personal ${ }^{65}$. La identidad se configura como el derecho a ser uno mismo y diferente de los demás. Podría afirmarse incluso, que la identidad es la que es, sin que haya posibilidad de alteración, lo que quizá sea un poco difícil de sostener en la realidad digital. Lo cierto es que hoy la reflexión sobre la identidad subjetiva pivota en torno a lo que se ha dado en llamar el "giro digital", el cual afecta a las relaciones entre los seres humanos, con la naturaleza y consigo mismos ${ }^{66}$. Actualmente podemos hablar de "identidades múltiples", una identidad física, formal, oficial y pública, que se define a partir de las circunstancias y del entorno público y recognoscible de cada persona ${ }^{67}$; y otra, $u$ otras identidades inmateriales, que se definen en función de los elementos que cada uno quiere que se resalten o le definan en el mundo digital. Es precisamente en este punto, según Piñar Mañas, en el que la privacidad asume un papel de primera magnitud, pues este nos permite mantener e incluso reivindicar la identidad que queremos para nosotros, o la que realmente tenemos, y que paradójicamente define asimismo la identidad que queremos mostrar hacia fuera. Por tanto, la privacidad permite controlar mi yo y expresar el yo que quiero transmitir a los demás ${ }^{68}$. Aquí es donde el derecho al ol-

65 V. MORENTE PARRA, “Big data o el arte de analizar datos masivos. Una mirada crítica desde los derechos fundamentales", Derechos y Libertades, núm. 41, 2019 pp. 225-260.

${ }_{66}$ F. J., ANSUÁTEGUI ROIG, "Nuove Tecnologie e Spazio pubblico”, en S. SALARDI, y M. SAPORITI, (eds.), Le tecnologie 'morali' emergenti e le sfide etico-giuridiche delle nuove soggettività, G. Giappicheli Editore, Torino, 2020, p. 27.

67 J. L. PIÑAR MAÑAS, "Identidad y persona en la sociedad digital", en T. DE LA QUADRA-SALCEDO y J. L. PIÑAR MAÑAS (Dir.), Sociedad digital y Derecho, cit., p. 97.

68 Ídem, pp. 97 y 98. 
vido $^{69}$ juega un papel decisivo, al garantizar una "segunda oportunidad", a través del derecho a cancelar o "borrar" definitivamente determinados episodios del pasado ${ }^{70}$, siempre que se demuestre que el tratamiento de dichos datos ya no es necesario para los fines para los que fueron recabados o que dichos datos son erróneos.

El derecho a la autodeterminación informativa podría ser entendido teóricamente como una válvula cuya llave está bajo nuestra custodia, abrimos o cerramos dicha llave en atención a elecciones "libres e informadas". Se trata, por tanto, de una facultad jurídica que nos dota de una serie de herramientas con las que gestionar nuestro patrimonio digital, es decir, nuestra información personal ${ }^{71}$. Las elecciones que hacemos en relación con la gestión de nuestros datos personales en internet parten, supuestamente, de una primera elección voluntaria e informada. Sin embargo, incluso esta libertad de autodeterminación informativa o de control de nuestros datos personales podría ser en realidad ilusoria, de tal modo que el "ciudadano digital" se estaría dejando transformar en "súbdito digital", perdiendo así la soberanía sobre su propia información personal y, por consiguiente, su identidad. Quizá en el contexto digital sea ilusorio entender que el desarrollo de nuestra personalidad es verdaderamente libre y autónomo, y haya llegado el momento de asumir que la construcción de nuestra identidad personal no depende únicamente de nuestras libres decisiones, sino que también encuentra una fuente heterónoma, distorsionadora de la percepción que tiene cada individuo de su propia identidad, como única

69 Artículo 21 del Reglamento (UE) 2016/679 de 27 de abril de 2016.

70 La capacidad de almacenamiento de información de internet, así como los silos informáticos en los que reside dicha información es, prácticamente, infinita, como la memoria de Funes. "Funes el memorioso" es un personaje de uno de los cuentos que integran la obra "Ficciones" de Jorge Luis Borges. Este personaje tiene la cualidad de recordar todo lo vivido a escala 1:1, lo que le lleva a emplear un día en recordar otro día y, por consiguiente, a no poder olvidar ni el más insignificante detalle. Internet es una especie de "Funes digital", puesto que puede recordarnos multitud de aspectos de nuestra vida pasada que ni siquiera nosotros recordamos, eso sí, mucho más rápidamente que el personaje de Jorge Luis Borges. J. L. BORGES, Ficciones, Alianza Editorial, Madrid, pp. 123 y ss.

71 Las herramientas de control sobre nuestra información integran lo que se ha dado en llamar: "habeas data". Esta figura jurídica está integrada a su vez por un conjunto de facultades a saber: derecho de acceso, derecho de rectificación, derecho de cancelación -derecho al olvido-, derecho de oposición, derecho a la limitación de los datos, derecho a la portabilidad de la información personal y derecho a no ser objeto de una decisión automatizada con consecuencias jurídicas o similares. Este catálogo de derechos, recogidos en el RGUEPD, ha sido ampliado por la ley española LO 3/2018 de 5 de diciembre de protección de datos personales y derechos digitales. 
e intransferible ${ }^{72}$. La identidad digital es fruto de un "relato simultáneo", es decir, la identidad digital no solo depende de nuestra narración, de nuestras acciones, omisiones o interacciones con otras personas, sino que es el resultado de un diálogo simultáneo y permanente que escapa a nuestro control. Este diálogo permanente de construcción de identidades digitales se desarrolla en lo que se ha denominado "identidad digital aumentada" que "potencia y proyecta las experiencias de los individuos y que permite transmitir pensamientos, imágenes y contenidos de forma instantánea a través de diferentes redes relacionales interconectadas entre sí" ${ }^{\prime \prime}$.

Inevitablemente, esto nos lleva a sospechar que en la sociedad digital, fruto del desarrollo tecnológico, el individuo disfruta de una "ausencia de libertad cómoda, suave, razonable y democrática" 74 , que diluye cualquier posibilidad de pensamiento crítico. La sociedad digital se habría convertido, por tanto, en una "factoría de identidades" creadas en serie, y cuya materia prima proviene de la ingente información vertida en internet, a través de nuestras consultas a páginas web, opiniones en redes sociales y de las múltiples aplicaciones que nos "hacen la vida más fácil", es decir, de nuestra huella digital. Lo que puede estar pasando es que "con la técnica no hemos ampliado el perímetro de nuestra libertad, sino que fingimos ser más libres que antes" 75 .

Si analizamos pormenorizadamente el control real que podemos ejercer sobre nuestra información personal, llegaremos a la conclusión de que el derecho a la autodeterminación informativa adolece del aquí denominado "déficit de la triple A". En primer lugar, ejercemos un control apriorístico sobre nuestra información personal, puesto que el consentimiento se manifiesta en un primer momento, como herramienta habilitante -y legitimadora- para el tratamiento de los datos personales. Una vez que se da el consentimiento, en la mayoría de los casos, se produce una pérdida de control efectivo, aflorando el segundo déficit, el del control aparente. Cuando subimos información personal a internet esta no se mantiene en un plano de realidad bidimensional, sino que se sumerge en las profundidades abisales del ciberespacio. La realidad digital es el Dios Jano, una de sus caras mira hacia las pantallas de nuestros dispositivos y ordenadores, y es en esa faz en la que ejercemos un

72 J. L. PIÑAR MAÑAS, “Identidad y persona en la sociedad digital”, cit., p. 102.

73 M. PÉREZ SUBÍAS, "Identidad digital”, en Telos. Cuadernos de Comunicación e innovación, Fundación Telefónica, 2012, p. 2 (disponible en www.telos.es).

74 H. MARCUSE, El hombre unidimensional, Ariel, Barcelona, 2016, p. 41.

75 J. M. LASALLE, Ciberleviatán, cit., p. 76. 
control aparente de nuestra información, mientras que con la otra cara mira hacia la profundidad del océano de datos que es internet, donde nuestra información ha podido ser copiada, compartida, combinada a través de la técnica del Big Data, o almacenada en los superordenadores de las grandes compañías tecnológicas. Por consiguiente, lo que era identificable, cuantificable, mensurable y personal, se ha convertido en metainformación sobre la que se pierde prácticamente el control. Por último, el poder soberano que ejerce un usuario de internet sobre su información personal es anecdótico, entendiendo por anecdótico lo que define la RAE como "un suceso circunstancial e irrelevante". En realidad, nuestro control efectivo se ejerce sobre una información personal epidérmica, reducida y primitiva. Se da una manifiesta pérdida del control jurídico sobre los datos combinados, sobre los metadatos, y sobre los perfiles obtenidos a través del análisis de datos masivos que llevan a cabo las empresas fundamentalmente a través de la técnica del Big Data, etc.

Las limitaciones que presenta el derecho a la autodeterminación informativa, así como la imposibilidad manifiesta de garantizar que la información circulante en internet sea veraz, obstaculizan considerablemente nuestra capacidad de comprensión, nuestro juicio crítico y la posibilidad de adoptar una decisión informada y, por consiguiente, libre. Este hecho también dificulta un libre desarrollo de la personalidad, puesto que en la sociedad digital no somos los únicos "hacedores" de nuestra identidad, sino que somos sujetos de identidades construidas a partir de correlaciones, de cálculos algorítmicos que predicen nuestras acciones o decisiones incluso antes de que las hayamos imaginado. Y si somos predecibles nuestra libertad es solo ensoñación, solo apariencia de libertad.

Llegados a este punto debemos plantearnos si en la sociedad digital podemos seguir disfrutamos de la libertad de los modernos tal y como la hemos definido en el primer epígrafe o, por el contrario, esta se ha convertido en un mero espejismo, en un trampantojo que tapa las vergüenzas de la "no libertad" en la sociedad digital. Entonces ¿estamos ante un espectáculo taumatúrgico? ¿Debemos dar por perdida ya cualquier posibilidad de mantener con vida la libertad de los modernos en la sociedad digital?

\section{3. “EL CONTROL DE LOS DATOS OS HARÁ LIBRES" O QUIZÁ NO. MÁS ALLÁ DE LA LIBERTAD DE LOS MODERNOS}

A la luz de todo lo expuesto, la sospecha de que en realidad no ejercemos una soberanía efectiva sobre nuestra información personal y, por consiguien- 
te, sobre la construcción de nuestra identidad digital, cobra mayor fuerza. Como ya hemos advertido, si no ejercemos un control real y efectivo sobre nuestros datos personales, entonces no podemos concebirnos plenamente libres en la sociedad digital. Al menos no podríamos ser libres en el sentido moderno de libertad del que hemos partido en este artículo. Sin embargo, la experiencia del partícipe de la sociedad digital es la de gozar de la máxima libertad que se haya conocido nunca. Vivimos, por tanto, en una permanente paradoja. Como usuarios de internet podemos acceder a multitud de medios de información, así como a múltiples canales y plataformas de comunicación. Además, gracias a que en internet se inmaterializa la información, lo inmaterial abarata y democratiza su acceso, por lo que podemos disponer de la mayor biblioteca jamás imaginada; podemos acceder a ingentes repositorios musicales, fotográficos y artísticos en general; podemos matricularnos, incluso de manera gratuita, en cursos impartidos en las mejores universidades del mundo; $y$, además, podemos crear empresas enteramente digitales que nos proporcionen un medio de vida con menores costes fijos, más visibilidad y mayor dinamismo.

Desde esta perspectiva, es innegable que el individuo nunca tuvo mejor oportunidad para informarse, formarse e instruirse de una manera plural y libre. Sin embargo, los individuos que integramos la sociedad digital somos conscientes de que el ejercicio de nuestras libertades en internet no es un juego de suma cero. Sabemos que nuestra libertad está bajo vigilancia, está sometida a un "tercer grado", por parte de los poderes que ostentan el control de los datos. Somos conocedores de la paradoja en la que vivimos y participamos conscientemente de la ficción del "como si" fuéramos libres y detentáramos un poder efectivo de autodeterminación sobre nuestra información, al menos en Occidente. Quizá de lo que no somos conscientes es del alcance verdadero de ese control ubicuo. Byung-Chul Han entiende que hemos llegado a un nivel tal de inconsciencia que ni siquiera nos autoconcebimos sujetos sometidos por un poder coactivo "amable y ubicuo", sino que nos concebimos como un "proyecto libre" que se reinventa constantemente ${ }^{76}$.

Si bien la democracia liberal moderna ya trajo consigo previamente, entre otras cosas, la secularización y desmitificación de los diferentes discursos públicos, la sociedad digital ha traído consigo el "mito de la libertad". Como determina Leszek Kolakowski "el mito solo puede ser aceptado si se convierte, para la mirada del individuo, en una suerte de imposición a la que está some-

76 B. CH. HAN, Psicopolítica, Herder, Barcelona, 2019, p. 11 y pp. 57 y ss. 
tida igualmente toda la sociedad en la que aquel participa. Por consiguiente, el mito configurador de valores implica una renuncia a la libertad en la medida en que impone un modelo acabado, y una renuncia a la absoluta inicialidad del ser humano en la medida en que lo inserta en una situación no histórica absolutamente originaria, le otorga una dimensión atemporal, adicional y procura vincularse comprensivamente con un orden atemporal" 77 .

Esta ensoñación colectiva sobre la libertad nos aboca al entendimiento de la libertad de los modernos, en el contexto de la sociedad digital, como un mandato de optimización. Según Robert Alexy los principios, a diferencia de las reglas, son mandatos de optimización y éstos, a su vez, se caracterizan por el hecho de que pueden ser cumplidos en diferente grado, así como porque la medida de su cumplimiento no sólo depende de las posibilidades reales, sino también de las posibilidades jurídicas; estas últimas vienen determinadas por los principios y reglas que juegan en sentido opuesto ${ }^{78}$. Es decir, ha de asumirse que la libertad negativa en la sociedad digital se comporta, en el mejor de los casos, como un principio que se aplica de manera gradual, y cuya optimización o maximización atiende tanto a condiciones prácticas como jurídicas. Si bien, las condiciones jurídicas en el contexto de la UE son más óptimas como para que la balanza caiga del lado de la libertad, no parece que sea así en todos los lugares ni en todas las circunstancias como ya hemos tenido ocasión de comprobar. Si, por el contrario, solo debiéramos entender el derecho a la libertad en la sociedad digital como una regla, es decir, plenamente exigible y aplicable a la manera de "todo o nada", podríamos correr el riesgo de quedarnos con el "nada". La tangibilidad de la regla se volatiliza en la sociedad digital que inmaterializa las relaciones jurídicas, de tal modo que la existencia de un derecho o una libertad no exige una realidad física previa, un bien jurídico material que proteger. Además, en la sociedad digital se podría estar produciendo lo que Ansuátegui Roig denomina la "contaminación tecnológica" de las libertades, lo que puede estar provocando la reformulación de los derechos antiguos, la aparición de nuevos derechos y libertades, así como la aparición de nuevas formas de vulneración de éstos ${ }^{79}$.

Todo ello aleja la posibilidad de que la sociedad digital se acabe convirtiendo en una comunidad política democrática en un sentido pleno, lo que

77 L. KOLAKOWSKI, La presencia del mito, Amorrortu, Buenos Aires-Madrid, pp. 33 y 34.

78 R. ALEXY, Teoría de los derechos fundamentales, Centro de Estudios Políticos y Constitucionales, Madrid, 2008, p. 87.

79 F. J. ANSUÁTEGUI ROIG, “Nuove Tecnologie e Spazio pubblico”, cit., p. 27. 
además dificulta una posible transición de la condición de usuario y cliente a la de ciudadano digital que se autodetermina. Una de las razones la encuentra Herbert Marcuse en el hecho de que la civilización contemporánea nos ha llevado a un estadio en el que la "sociedad libre" no se puede definir adecuadamente en los términos tradicionales de libertades económica, intelectual o política, por lo que se necesitan nuevos modos de realización que correspondan a las nuevas capacidades de la sociedad. Por ejemplo, afirma Marcuse la libertad política -lo que Berlin denomina libertad positiva- actualmente significa la liberación de los individuos de una política sobre la cual no ejercen ningún control efectivo, y de lo que somos plenamente conscientes ${ }^{80}$. Además, puede que seamos colaboradores necesarios en este "liberticidio", ya que como advierte Constant: los hombres modernos prefieren el comercio a la política activa, de tal modo que desde la Modernidad el comercio es el estado normal, el fin úni$\mathrm{co}$, la tendencia universal, la vida verdadera de las naciones ${ }^{81}$.

Sin embargo, quizá en el futuro, los usuarios de internet salgan de la caverna y tomen el poder digital, a través del control de su información personal, haciendo así realidad el ideal emancipatorio de la libertad moderna. Si esto sucediera los ciudadanos digitales estarían en disposición de pactar un "contrato social", a través del cual responder a las preguntas de ¿quién manda? ¿cómo se manda? y ¿qué se manda? Preguntas a las que podríamos responder con el modelo de la democracia liberal representativa que reconoce y garantiza los derechos humanos. Con ello, se habría resucitado la libertad de los modernos de Constant para la sociedad digital. Sin embargo, hay que tener en cuenta, como ya hemos advertido, que la tradición moderna ha vinculado la libertad con la idea de "individualismo posesivo", según advierte Crawford B. Macpherson, y que destaca en las siete proposiciones siguientes: 1) lo que hace a un hombre ser libre es ser libre de la dependencia de las voluntades ajenas; 2) la libertad de la dependencia ajena significa libertad de cualquier relación con los demás salvo aquellas en las que el individuo entra voluntariamente por su propio interés; 3) el individuo es esencialmente propietario de su propia persona y de sus capacidades, por las cuales nada debe a la sociedad; 4 ) aunque el individuo no puede enajenar toda su propiedad

80 H. MARCUSE, El hombre unidimensional, cit., pp. 43 y 44.

81 Afirma Benjamin Constant que "El comercio inspira a los hombres un vivo amor por la independencia individual, atiende sus necesidades y satisface sus deseos sin intervención de autoridad, y que, en el caso de darse dicha intervención, sería entendida como una molestia y un trastorno" B. CONSTANT, "La libertad de los antiguos comparada con la de los modernos", cit., pp. 84 y 85. 
sobre su propia persona puede enajenar su capacidad para trabajar; 5) la sociedad humana consiste en una serie de relaciones mercantiles; 6) dado que lo que hace humano a un hombre es la libertad de las voluntades ajenas, la libertad de cada individuo solo se puede limitar justamente por unas obligaciones y reglas tales que sean necesarias para garantizar la misma libertad a los demás; 7) la sociedad política es una invención humana para la protección de la propiedad que el individuo tiene sobre su propia persona y sobre sus bienes para el mantenimiento de relaciones de cambio debidamente ordenadas entre individuos considerados como propietarios de sí mismos.

Es posible que haya llegado el momento de preguntarnos si este modelo de libertad puede tener acomodo en la sociedad digital o debemos transitar hacia otro modelo de libertad menos individualista y, sobre todo, menos posesiva. Byung Chul Han apuesta por abandonar el concepto de "libertad individual", propio del neoliberalismo, y dirigirnos hacia un modelo de libertad relacional. Afirma este autor que el aislamiento total al que nos conduce el régimen liberal no nos hace realmente libres ${ }^{82}$. De esta manera pretende desvincular a la libertad del individualismo posesivo. Como ya ha advertido Macpherson, el liberalismo entiende al sujeto como "empresario de sí mismo", y como empresario también en sus relaciones con los demás, ya que el rendimiento económico constituye la razón última de las relaciones interpersonales. El ánimo mercantil parece constituir el sustrato último de la sociedad digital, en la que se promueven las relaciones interpersonales con la finalidad de conseguir una población cautiva objetivo de un marketing personalizado. Sin embargo, la autonomía individual no tiene porqué identificarse con el individualismo posesivo y patrimonialista con el que se ha vinculado al liberalismo desde la Modernidad. Podemos entender la libertad personal o la autonomía individual como la capacidad que puede generar una persona de reflexionar, no solo sobre sí misma, sino también sobre su entorno y sobre los demás agentes intervinientes en ese mismo entorno. Esa posibilidad de reflexionar sobre un "yo relacionado con otros", permite a la persona integrar otras realidades en sus decisiones. De esta manera, el individuo ejerce su "autonomía relacional" al tomar una decisión libre y comprehensiva de las relaciones interpersonales que delimitan su entorno social ${ }^{83}$.

Un claro ejemplo de los límites del individualismo posesivo lo encontramos en los Estados de Derecho, en los que la ciudadanía no ejerce un poder

82 B. CH. HAN, Psicopolitica, cit., p. 13.

83 S. ÁLVAREZ MEDINA, La autonomía de las personas. Una capacidad relacional, El Derecho y la Justicia, Centro de Estudios Políticos y Constitucionales, Madrid, 2018, p. 45. 
absoluto sobre sus propios bienes, incluso tratándose de sus datos personales. Los individuos desarrollan sus vidas en sociedades en las que la información y la comunicación resultan imprescindibles para la seguridad de la comunidad política, por lo que su información personal puede quedar expuesta al juego de la ponderación. Por esta razón, la información, aún aquella que se refiere a datos personales, ofrece una imagen de la realidad social que no debe ser patrimonio exclusivo del interesado. Si todos cedemos información al ámbito público, posiblemente esto pueda revertir positivamente sobre nosotros mismos. Esto se ha puesto claramente de manifiesto con la pandemia del Covid-19. La crisis mundial del coronavirus nos ha hecho tomar conciencia de la debilidad del argumento del interés privado frente al imperio de la salud pública y del interés general. El bien de la salud pública no solo justifica la limitación de la libertad de movimiento entre otras, sino que, además, justifica la cesión tácita al Estado de nuestros datos sanitarios. Esto supone abandonar un modelo de "consentimiento informado" rígido -como el que contempla el RGPD (Reglamento General de Protección de Datos de la UE) - y transitar hacia la consolidación de un modelo "optout" u opción salir. Es decir, a menos que el sujeto titular de la información sanitaria exprese lo contrario, sus datos pasarán a formar parte del flujo de datos públicos del que se nutren tanto las medidas de salud pública, como la investigación sanitaria pública, cuya fundamentación última se encuentra en el criterio del interés general ${ }^{84}$. Este modelo presume el consentimiento, es decir, se aplica un consentimiento tácito por defecto, como sucede en el sistema español de donación de órganos y, de ahí, su éxito mundial.

En su versión más amplia, este "modelo de consentimiento presunto", posibilitaría un uso privado de los datos sanitarios y, por consiguiente, permitiría que las empresas privadas se lucrasen de dicho patrimonio público. Si bien es cierto que esta idea puede generar reticencias, ya que la industria

84 Como advierte Federico de Montalvo "seguir asentando el modelo legal en el postulado de que la enfermedad y sus datos sólo les pertenecen a quienes sufren aquélla y no a los demás es, en nuestra opinión, ignorar la realidad. A este respecto, debemos recordar que la protección de datos no es, ni nunca ha sido, un fin en sí misma, sino que, más bien, sirve para proteger a la persona en el libre desarrollo de su personalidad, tanto en su esfera privada como en la esfera pública". Mantener una posición que ignore el beneficio colectivo de los datos sanitarios no está primando la autonomía, sino el egoísmo y el narcisismo. Véase F. DE MONTALVO JÄÄSKELÄINEN, “Una reflexión desde la teoría de los derechos fundamentales sobre el uso secundario de los datos de saluden el marco del Big Data", Revista de Derecho Político de la UNED, núm. 106, 2019, p. 53. 
farmacéutica y sanitaria busca maximizar su beneficio económico, no es menos cierto que sus resultados -bienes y servicios sanitarios- pueden repercutir muy positivamente en la calidad sanitaria de la sociedad en su conjunto. Además, ha de tenerse en cuenta que el sector sanitario está regulado y limitado por el "deber de secreto", base fundamental de la relación de confidencialidad entre el personal sanitario y el paciente, y que viene a reforzar la seguridad en el tratamiento de los datos personales. La investigación coparticipada entre lo público y lo privado es, seguramente, lo más eficiente e inteligente actualmente, y será con toda probabilidad lo que permita el éxito en la investigación de la vacuna del Covid-1985.

Es indudable que nos encontramos ante un triste hito histórico que ha arrojado a la humanidad a la mayoría de edad de manera abrupta. Quizá haya llegado el momento de "atrevernos a saber" que seguramente a partir de ahora no dispongamos de un control pleno sobre nuestros datos sanitarios, sobre nuestros hábitos de vida y sobre nuestra ubicación geográfica, al menos hasta que la amenaza de una pandemia se disipe totalmente. Posiblemente este hecho provoque el inicio de una reflexión colectiva que nos haga tomar conciencia de cuál es el valor real que tiene nuestra información personal en la sociedad digital y exijamos tomar el control para gestionarla con la finalidad de que revierta en el bien colectivo. De este modo, quizá podamos abandonar el individualismo radical que dirige la vida occidental y que da origen a la concepción patrimonialistas de la realidad y, por consiguiente, de nuestra información personal.

\section{CONCLUSIONES}

Si bien la Modernidad trajo consigo la libertad individual, entendida como espacio privado de no interferencia, quizá haya llegado el momento de superar esta concepción y de abrirnos a realidades colectivas que exigen nuestra implicación y colaboración más directa. La sociedad digital demanda una idea de libertad relacional, entendida como la capacidad de desarrollar nuestra personalidad de manera autónoma, aunque en conexión necesaria con el entorno social, es decir con el marco de relaciones interpersonales en el que nos integramos. Esto puede ayudar a desvincular el derecho a la auto-

85 El NIH (Institutos Nacionales de Salud) ha creado una asociación público-privada para acelerar el desarrollo de una vacuna contra el Covid-19.

DERECHOS Y LIBERTADES

ISSN: 1133-0937

Número 45, Época II, junio 2021, pp. 199-231

DOI: https://doi.org/10.20318/dyl.2021.6106 
determinación informativa de la idea de un espacio virtual de dominio privativo, y de carácter patrimonial, que ha imperado en los últimos tiempos.

Por otro lado, debemos tomar conciencia de cuál es la verdadera naturaleza de la sociedad digital y de cuáles son las posibilidades reales de democratizar dicho espacio que, como ya hemos advertido, aglutina diversas dimensiones y no todas son de carácter político. De cualquier modo, ha de tenerse en cuenta que para ser "ciberciudadanos" primero tenemos que estar dispuestos a actuar como tales, tenemos que desear tomar el control y ejercerlo de manera democrática. Incluso, podríamos ambicionar la "libertad de los antiguos", a través del ejercicio de la democracia directa, ya que internet nos ofrece un espacio perfecto para desarrollar nuestra autodeterminación política.

De momento, la realidad de la sociedad digital nos recuerda que seguimos en régimen de libertad vigilada. Y quién sabe si el efecto anestésico de los nuevos tiempos nos haga dejar de anhelar la libertad de los modernos, cuando ya nos hayamos acostumbrado al confinamiento custodiado de la sociedad digital.

\author{
VAnesa Morente ParRa \\ Filosofia del Derecho \\ Universidad Pontificia de Comillas ICADE \\ c/ Alberto Aguilera, 23 \\ 28015 Madrid \\ e-mail:vanesamorente1980@gmail.com
}

